\title{
Understanding the Role of Imami Shiites in Historiography from the Fifth through the Seventh Centuries AH
}

\author{
Mohammad Taher Yaghoubi ${ }^{1}$ \& Mohammad Ali Chelongar ${ }^{2}$ \\ ${ }^{1}$ History Department, Islamic History Isfahan University, Isfahan, Iran \\ ${ }^{2}$ History Department, History Department Isfahan University, Isfahan, Iran \\ Correspondence: Mohammad Taher Yaghoubi, History Department, Islamic History Isfahan University, Isfahan, \\ Iran. Tel: 98-912-253-5141. E-mail: Taher113@gmail.com
}

Received: July 30, $2012 \quad$ Accepted: September 19, $2012 \quad$ Online Published: December 28, 2012
doi:10.5539/ach.v5n1p84

\begin{abstract}
During the fifth to the seventh centuries after Hegira, the Shiites did not have significant political power in the Islamic World and had a minority population. Yet despite these limitations, the Shiites left behind numerous works a large part of which is destroyed by religious prejudices or negligence leaving the Islamic Civilization bereft of these scientific treasures. By introducing the historiographical works of the Imami Shiites, this study attempts to clarify their station in historiography and to demonstrate that Shia has had valuable works in different historiographical fields in proportion with sociopolitical circumstances and thereby address the richness of Islamic culture and civilization and show that deprivations have had no influence on Shia's creation of scientific works. Furthermore, Shiites' attention to historiography in different fields including Rejaal (Note 1) and Taraajom (Note 2), Dala'el (Note 3), history and lives of the Innocent Ones (Ma'sumin) and historical-theological books and using Hadiths have been very important in compiling these works.
\end{abstract}

Keywords: Imami Shiites, historiography, historiographers, historical books, Hadith aspects

\section{Introduction}

One of the characteristics of Islamic historiography is its extensiveness which indicates the attention paid to the science of history in Islamic culture and civilization. The interest and persistence of Imami (Note 4) Shiites in historiography is an undeniable fact because it originates from the verses of Koran and the prophet's Sunnah and Imams' recommendations as it is the case in Imam Ali's letter to his son in which he emphasizes paying attention to the past generations and says, "My son, though I have not lived as much as all the people behind me, I have observed their actions, contemplated on their lives and gone and seen what is left of them and now I have become one of them as if I have lived with the first and last of them (Dashti, 1382).

Despite Islam and the Imams' emphasis on the study of history, it is presumed that the Shiites, compared to other Muslims, have been less interested in history; however, a review of Islamic and Shiite historiography shows that the Shiites have not been negligent of history and numerous, valuable works in history left by them is a proof of this claim. But there are reasons for their unproductivity in the field of historiography in some certain periods: some part of history is related to exposing and telling about right and wrong and their proponents, which, considering the political situation of the times, has been less possible because the proponents of the right, particularly the Shiites, have been under various political, military and propagandist pressures and in some cases the Shiites have had to resort to dissimulation in order to save their lives and wealth. In fact, political and ideological factors have been very important in the Shiites' limitations to write historical books. Political rulers usually supported books and writings which were in line with their desires and to their advantage. It is obvious that in most of the periods in Islamic history as well as in the middle periods, political rule and social power was in the hands of those who were one way or another, supporters of the Sunnites. Therefore, scientific and cultural circles were dominated by that thinking. In spite of these conditions, the Imami Shiites were not negligent of this fact during various historical periods, including the fifth through the seventh centuries after Hegira, and did their best in creating historical works and left behind them numerous and valuable works in proportion to the Shia population in Islamic lands and despite their little influence in political rule and power. What is important in the works written by Shiites is the dominance of the Hadith aspects which is the effect of the aforementioned limitations. From all types of historiography, the Shiites wrote works which were mostly related to their beliefs. 
Explaining Shiite tenets and demonstrating the rightfulness and worthiness of the Imams were among the most important points, and using Hadiths and sayings of Imams in these works is of extreme importance. Indeed, Hadith and history are closely related. In this regard, the emphasis is sometimes on history and sometimes on Hadith as numerous historical instances are found in some Hadith works. In addition, there are many historical books in which using Hadiths is clear because of the subject and materials introduced.

The questions addressed by this article are:

- How much have been the Shiites persistent and important in historiography of this period?

- In which historiographical branches have Shiites been more successful and persistent?

- How much and why has Hadith been important in the Shiites' historiography?

Introducing the historical works of the Shiites in different historiographical periods further indicates the fact that the Shiites have left numerous works in historiography. Nevertheless, in some branches of historiography such as general and local history not many works by Shiites are noticed because writing such books required praising and mentioning rulers and their lives which was against the Shia principles. Notwithstanding the restrictions and obstacles during the period between the fifth through the seventh centuries (AH) which was contemporaneous with the last years of the Buyid Dynasty to the fall of the Abbasids in Baghdad, the Shiites were always present in the scientific arena and scientific and cultural circles. Among these fields in which some Imamiyeh writers shined was historiography because they were aware of the importance of the fact that history and historiographers' reports are very critical in introducing people and directing thinking, cultural and political lines. Introducing historical works of the Shiites in different historiographical fields can reveal how much persistent and successful they have been and what attitudes they have had in this field.

\section{Rejaal and Taraajom}

Rejaal is a science that discusses some of the characteristics of Hadith narrators which are important in acceptance or rejection of their narrations (Sobhani, 1415). Taraajom which is considered Rejaal's sister is a science that discusses lives of scientific, social or political figures, whether Innocent or non-Innocent Hadith narrators (Ibid). From these definitions the importance of Hadith in these books is revealed. Introducing those dignitaries and Imami narrators and Imamyieh scientists who have had works in the field of Taraajom and introducing their works in these two sciences explains the important role of the Imami Shiites in expanding the fields of Taraajom and Rejaal. There have been numerous Shiite works in the fields of Taraajom and Rejaal from the fifth century onwards and even before the fifth century some works have been written in these fields.

An overview of the works on Rejaal in this period shows that the four Shiite Rejaal books, namely Al-fehrest, Rejaal wa Ekhtyiar, Toosi's Ma'refat-ul Rejaal, and Najjashi's Rejaal, are written in this period and most of the books written after these have been written either as imitations of these books or as supplementary to them. Of course, we have to mention other important Rejaal books such as Ibn-E Qazaeri's Rejaal or Ibn-E Abi Tey's Rejaal and Taraajom books which contain invaluable information unavailable today, but have been used by famous Sunnite historiographers. The importance of Taraajom and Rejaal books is that they introduce Shiite luminaries and their valuable works in different sciences. They also show the persistence and role of Shiites in the area of science and culture. The most important books in this field are:

1. Najjashi's Rejaal; Abul Abbas Ahmad Ibn-E Ali Ibn-E Ahmad Ibn-E Abbas Najjashi Asadi, known as Ibn-ul Kufi (died AH 463) whose books is in the category of Shiite Rejaal principles. Najjashi's Rejaal, in fact, is exclusively about the written heritage of Shia as the author of the book Mo'jam Rejaal-ul Hadith states that Najjashi has forced it upon himself to mention the names of Imamyieh authors in his book. Therefore, anyone from whom Najjashi has presented a translation is definitely an Imami unless he specifies his being not an Imami or corruption of his faith, as he has done this in some cases (Musavi Khui, 1403). Najjashi in his book makes a list of Shiite books and writings in all sciences and in Taraajom Rejaal he refers to the list of Sheikh-e Toosi and some consider Najjashi's book a supplementary and the first appendix to Toosi's (Toosi, 1424). In total, Najjashi introduces 1269 Shiite writers. In expressing his purpose for compiling the Rejaal, Najjashi states that it is a response to the accusations made by opponents that Shia has no background in writing (Najjashi, 1408).

2. Works by Sheikh-e Toosi; Abu Ja'far Muhammad Ibn-E Hassan Toosi (died AH 460) is considered a Shiite scientist and dignitary and somehow we may say that Shiite Rejaal is summarized in him. Three of the four Shiite Rejaal principles books are written by him. Sheikh Toosi was an authority in Rejaal as well as in religious jurisprudence. Toosi's Rejaal books include: 
A. Al-Fehrest; in this book, names of authors are arranged not categorically, but alphabetically. It is stated by the author himself in the introduction (Toosi, n.d.). One of the sources for his book has been Ibn-E Nadim's Fehrest (died second half of the fourth century AH) which Toosi uses on many occasions (Tehrani, 1408). Also, some famous Rejaal books such as Ma'alem-ul Olama by Ibn-E Shahrashub, Montajebuddin's Fehrest and Mohaqeq Helli's Rejaal are written in imitation of and influenced by Al-Fehrest (Tehrani, 1408).

B. Rejaal; Toosi's Rejaal contains narrators and followers (Note 5) of The Innocent Ones which are arranged alphabetically and categorically in thirteen chapters. The first chapter mentions the followers who have narrated from the prophet. The fifth through the twelfth chapters mention the followers who have narrated from the Imams. And the thirteenth chapter mentions those who have not narrated directly from the Imams. In the book Rejaal, Sheikh Toosi separates those who have directly narrated from the Imams and those who have not. Therefore, if he mentions someone among the followers of one of the Imams but does not include him in the thirteenth chapter, it means that the person has definitely a narration from that Innocent Imam (Shushtari, 1422). Furthermore, Sheikh Toosi inquires into the followers of The Innocent Ones and does not question their authenticity and alteration as it is the case with Moavieh and Amru Ibn-E Aas whom he mentions as the followers of the prophet and Zyiad Ibn-E Obayyeh and his son Obeyd-ullah Ibn-E Zyiad as followers of Imam Ali and Mansur Davaniqi as one of the followers of Imam Sadeq (Ibid, p. 29).

C. Ekhtyiar Ma'refat-ul Rejaal; this book is in fact a collection of selections from the book Ma'refat-ul Naqelin An-el Aemmat-al Sadeqin by Muhammad Ibn-E Omar Ibn-E Abdul Aziz Kashshi? (died around AH 367) and Sheikh Toosi dictated it to his pupils in AH 456. A particular feature of this book among the four Shiite Rejaal books is that there are useful information in this book on different Shiite sects and creeds such as Qollat, Fatiheh, and Zeydyieh. In general, this book is considered one of the most important resources in studying different movements in the times of the Imams (Tehrani, 1408).

3. Ibn-E Qazaeri's Rejaal; It is written by Abu Hussein Ahmad Ibn-E Hussein Obeydullah Qazaeri, known as Qazaeri (died first half of the fifth century AH). Two books in Rejaal are ascribed to Ibn-E Qazaeri. One is called Mamdoohin and the other one Zoafa. The books existing now, published as Ibn-E Qazaeri's Rejaal is actually the same Al-zoafa book which Ahmad Ibn-E Tavoos Helli (died AH 473) inserted in his Hal-ul Eshkal and mentioned it next to the four Rejaal books and he called them the Five Rejaal Books (Tehrani, 1337).

4. Works of Ahmad Ibn-E Nooh Sirafi (Died before AH 460); Ahmad Ibn-E Ali Ibn-E Abbas Ibn-E Noah Sirafi, a Najjashi master, has had many works which are not available today. One of his famous works was Akhbar-ul Wokala-el Arba'a or Akhbar-ul Abwab. This book has been frequently used in Toosi's Al-Qeybat (Toosi, n.d). Another of his books was Al-Zyiadat Ali Ibn-El Abbas Ibn-E Saeid (Ibn-E Oqdah) about the narrators from Imam Sadeq (Najjashi, 1408). The author of Mostafal Maqal maintains that Ibn-E Nooh's Al-Zyiadat is, in fact, supplementary to Ibn-E Oqdah's book. Ibn-E Oqdah names four thousand genuine followers of Imam Sadeq, but Ibn-E Nooh had already mentioned some one-fourth or one-fifth more than this number; therefore, the number of Imam Sadeq's followers has been more than we know of (Tehrani, 1337).

5. Al-Fehrest; it is the work of Sheikh Montajebuddin Abul-Hassan Ali Ibn-E Obeydollah Ibn-E Hasan Ibn-E Babuyeh (died AH 585). His famous work is Fehrest Asma' Olama-ul Shi'a wa Mosannfeihom. Like many other Rejaal books, this one is also a supplementary and appendix to Sheikh Toosi's Fehrest. In this book, the author names the Shiite Sheikhs since the time of Sheikh Toosi who were not mentioned in Toosi's Fehrest because of their contemporaneity with him to the Sheikhs of his own time (Afandi). Al-Fehrest describes the cultural presence of the Shiites in the city of Rey in the sixth century. From reading this book we find out that renowned Shiite scholars have been living in this city and every so often there have been debates between them and Sunnite scholars.

6. Works of Ibn-E Shahrashub; Abu Abudllah Muhammad Ibn-E Ali Ibn-E Shahrashub-e Mazandarani (died AH 588) was a great Shiite scholar. He had two books in Rejaal and Taraajom. Ma'alem-ul Olama which completes Sheikh Toosi's Al-Fehrest introduces those Shiite scholars and their books which had not been cited in Sheikh Toosi's Al-Fehrest or had lived after Sheikh Toosi to the time of the author. In the introduction to his book, Shahrashub states that he added around 600 books based on the names cited by Sheikh Toosi and instead shortened Sheikh's list in many cases (Ibn-E Shahrashub, 
1380, Int., p. 20). Another book by Ibn-E Shahrashub was Al-Rejaal and it is different from Ma'alem-ul Olama (Ibid, p. 1).

7. Al-arba'un Hadithan; it is written by Abu Hamed Mohyeddin Muhammad Ibn-E Abdullah Ibn-E Ali Ibn-E Zohreh (died AH 626), Imami jurisconsult and nephew of Abul Makarem Ibn-E Zohreh, a great Shiite jurisconsult. One of his existing works is the book Al-Arba'un Hadithan in which he cites translations of some great Sheikhs (Tehrani, 1337) and among its Hadiths is Imam Sadeq's letter to the governor of Ahwaz which Ibn-E Zohreh brings in his books with evidence (Majlesi, 1983).

8. Works of Ibn-E Abi Tey; Yahya Ibn-E Tey Hamid Ibn-E Zafer Ibn-E Ali, known as Ibn-E Abi Tey (died AH 630 or 635) is one of the most prominent Shiite scholars, living in Aleppo, who had numerous works in history and Rejaal and Taraajom which are, unfortunately, lost. He had several works in Taraajom and Rejaal:

A. Tarikh-al Shi'a-tal-Imamyiah: in his History of Islam, Zahbi says, "this book has been in several volumes and I have frequently quoted from it" (Zahbi, 1409). Also, Zahbi, in his books Siar A 'lam-ul Nobala' and Al-ebar and Ibn-E Hajar in his two books Lesan-ul Mizan and Al-esaba' fi Tamiz-u Sahabah and Safdi in his two books Nokat-ul Hamyan fi Nokat-ul Amyan and Alwafi Bel-vafyiyat have cited the Taraajoms of some Shiite scholars from this book which are collectively published in a book titled Recoveries of Ibn-E Abi Tey's Tarikh-al Shi'a (Ja'farian, 1379).

B. Al-Hawi fi Rejaal-al Shi'a-tal Imamyiah; it is one of the important works of Ibn-E Abi Tey, describing lives of Imamyieh religion's dignitaries, which is unluckily lost. This book has been used and cited from by Zahbi and particularly by Ibn-E Hajar and what is left of Al-Hawi is published in a collection titled Shiism in Aleppo and Remains of Al-Hawi (Ibid). What is left of Ibn-E Abi Tey's books gives helpful information on biographies and Taraajom which can help in understanding Shiite history, especially in Syrian areas and great Shiite scholars' (such as Ibn-E Zohreh Family) scope of influence.

In sum, we have to say that the Rejaal heritage of Shia fundamentally owes to the invaluable compilations of Sheikh-ul Taefah Abu Ja'far Muhammad Ibn-E Hassan Toosi (died AH 460) and from among the four main Shiite Rejaal books which have come to us three books which are important sources of subsequent books until today belong to Sheikh Toosi. Najjashi's Rejaal is the fourth book of the four main Shiite Rejaal books which is apparently an adaptation of Toosi's Al-Fehrest and in some cases revises and interprets it and contains new entries. These books along with other works which were subsequently written as supplementary, namely Ibn-E Shahrashub's Ma'alem-ul Olama, Montajebuddin Razi's Fehrest, and Ibn-E Qazaeri's Rejaal could be considered as Shia's cultural history from the beginning to near the end of the sixth century after Hegira.

\section{Genealogies}

Shiites have been forerunners of this branch of historiography and authors such as Muhammad Ibn-E Saeb Kalbi and his son Hosham (died AH 206), author of the famous Jamhorat-un Nasab, are proof to this claim (Haji Khalifeh, 1412). The importance of genealogical books associated with Hadiths is that knowing the lineage of Hadith narrators is a critical factor in the validity of Hadiths. In this period, though the Shiites had numerous books on genealogy, the larger part of these books is lost and not available today. Sunnite scholars have also written comprehensive and authentic books on the subject of genealogy in this period including Jamhorat-un Nasab by Hazm Andalusi (died AH 456) which is considered one of the most complete genealogical sources and Sam'ani's (died AH 562) Al-ansab which is one of the authentic sources of genealogy used by Sunnite and even Shiite scholars in the subsequent centuries. As we will describe later in introducing Shiite works, great Sunnite historiographers such as Zahbi and Safdi acknowledge the remarkable ability and knowledge of the Shiite scholars in genealogy and their attention to this branch of historiography. Most important works of Shiites in genealogy include:

1. Ibn-E Sufi's Works; Sayyid Abul-Hassan Najmuddin Ali Ibn-E Abel-Qanaem Muhammad Ibn-E Ali Alavi Omari (living in AH 443) frequently visited Baghdad and met Sayyid Razi and Sayyid Mortaza. In his time, the science of genealogy was exclusive to him. He had four books in genealogy:

1. Al-Majdi fi Ansab-el Talebin which is arranged in the form of genealogy and is available to us; 2. Al-mabsut; 3. Al-shafi; and 4. Al-moshajjar (Ibn-E Enabeh, n.d.; Tehrani, 1408).

2. Works of Jamal-uddin Abivardi; Abul Mozaffar Jamal-uddin Muhammad Ibn-E Abel Abbas Ahmad Ibn-E Ahmad Ibn-E Muhammad Omavi Abivardi (died AH 507) had three works in genealogy including: 1. Qobsat-ul Ejlan fi Nasab-e Alo Ab Sefyan; 2. Mal-ekhtelaf wa Ma'talaf in Arab genealogy; and 3. A great book on genealogy (Hemavi, 1408; Mohsen Amin, 1403). 
3. Works of Rashid-uddin Muhammad Alavi Husseini Obeydli Javvani Mesri (died AH 588); his works in genealogy are: 1. Tarikh-ul Ansab wa Menhaj-ul Sawab; 2. Tabaqat-ul Nasabyin-al Talebin; 3. Al-johar-ul Maknun fi Marefat-ul Qabael wal-botun: concerning Arab and Hashemyin genealogy; 4. Al-Tohfat-ul Sharifa Wal-hadayal-Manifah fi Nasab-un Nabi: in this book, he mentions the Prophet's children and uncles. Some copies of this book are existing; and 5. Tohfat-ul Ansab which is existing (Manzari, 1401; Kahaleh, n.d.).

4. Works of Muhammad Ibn-E As'ad-Abu Ali (died AH 588); he has been a luminary of his time in poetry, literature and genealogy. His books about genealogy include: 1. Tabaqat-ul Talebin; 2. Taj-ul Ansab; Rozat-ul Ensyieh Befazle Mashhad-ul Sayyidata Nafisa; and 4. Al-Tohafat-ul Sharifa Wal-hadayal-Manifah fi Nasab-un Nabi (Zarakli, 1989; Tehrani, 1408).

5. Works of Abu Taleb Marvezi; Abu Taleb Aziz-uddin Ismael Ibn-E Hussein Ibn-E Muhammad Hassan Alavi Mashhad Marvezi Azvarqani (died after AH 614) whose lineage goes back to Muhammad Dibaj, son of Imam Sadeq. He was most knowledgeable in genealogy, syntax, language, poetry, methodology, and astronomy (Hemavi, 1408). He had numerous works including in genealogy which are: 1 . Qanyiat-ul Taleb fi Nasab Al Abi Talib; 2. Kholasat-ul Etrata-n Nabavyieh fi Ansab-el Mousaviyah; 3. Bahr-ul Ansab Fima Lel-Sebtayn Men-al A'qab: the first part of this book is about the children of Imam Hassan Mojtaba and the second part about the children of Imam Hussein; a copy of this book exists in Al-zaviat-un Naseryiah Library in Maghreb (Mar'ashi, 1410); 4. Al-Ta'lyiah Ala Serr-el Ansab which the author himself (Marvezi, 1409); 5. Al-fakhri fi Ansab-el Talebyin which is his famous work. Abu Taleb Marvezi was both Fakhr Razi's disciple and his master and wrote Al-fakhri in response to his request and presented it to him and Fakhr Razi read it out to him and called him his master in this field; that is why the book is titled Al-fakhri (Tehrani, n.d.).

\section{Historical Theological Books}

Part of Shiite theological works has led to historical debates in proportion to the importance of the debates about Emamat among Shiites. As a minority group, Shiites have always sought to prove their rightfulness and defend their beliefs. One of the most effective ways in this path was creating works and books relevant to this subject because written works are, firstly, durable and will be handed to the posterity as historical evidence. Secondly, they provide the advocates of the religion the opportunity to present their explanations and answer possible criticisms and assaults, as the author of Al-naqz did, in a safe atmosphere. Historical-theological books by Shiite scholars are created for the same reason so that they can defend Shiite beliefs in a scientific and logical atmosphere and propagate Shiism. Nabavi (Note 6) and other Hadiths are the most important tools for the authors of these books in proving the rightfulness of Shiism and its leaders. Although these works are written to defend Shiite beliefs, they contain valuable information about history of Shiism, particularly in the field of culture. In fact, achievements and successes of the Shiites in different fields are presented in proportion to the theological discussions introduced to defend Shiism and refute opposing views.

1. Al-naqz; it is one of the historical-theological works of the sixth century AH. It is written by Nasir-uddin Abd-ul Jalil Ibn-E Abe-l Hussein Ibn-E Abel-Fazl Qazvini Razi (living in AH 560) was a prominent Shiite orator and scholar. The complete title of his book is Ba'zo Mathaleb Navaseb fi Naqze Ba'zo Fazaheu-l Ravafez meaning "some defects of Nasebyin, in refutation of the book on some disgraces of Rafezyin", which is condensed to Ketab-ul Naqz. This book, written in Persian, is in response to and rejection of some unjust accusations made by one Sunni writer living in Rey in his book Ba'zo Fazaheu-l Ravafez against the Shiites. This book was penned in AH 555 (Tehrani, 1408). Although this book was written in response to and refutation of accusations against Shiites, it contains valuable historical information and the historical importance of the book is related to the reports it gives about the sociopolitical conditions of the time. The author mentions important cities and areas of the Sunnites such as Isfahan, Hamadan, Saveh, Qazvin and Azerbaijan versus important Shiite cities including Qom, Kashan, Abeh, Mazandaran and Sabzevar and describes the status of the Shiites during that time. One of the valuable subjects addressed in this book is the Shiites' cultural, religious situation and their schools and scientific centers in this area.

2. Al-Ehtejaj Al Ahl-el Lejaj or Tabarsi's Ehtejaj; (first half of the sixth century AH) it is a historical-theological book about the arguments (Note 7) and debates of the Prophet and Shiite Imams and arguments of some of Imams' followers versus opponents and followers of non-Islamic religions concerning the essentials and secondary principles of Islam and 12-Imam Shia faith. There also some of the letters of Imam Zaman delivered through The Four Deputies (Note 8) during the Minor Occultation and some explanations from The Sacred Place (Note 9) to some scholars come at the end of the books. 
Most of the narrations are in the form of Morsals (without a complete sequence of evidences) and that is because most narrations used are either Motevater (with a complete sequence of evidences) or there is consensus about them or they are famous in the opposing and favorable books (Ibid).

3. Al-taraef fi Ma'reft Mazaheb-ul Tavaef; written by Sayyid Ibn-E Tavoos, Ali Ibn-E Musa (died AH 664). This book contains theological and historical observations in criticizing opposing religions. The author adopts a particular method in proving Shia faith. He assumes being someone who has just become a Moslem after which he notices disputes between Moslems and sees various sects and therefore decides to search in religious sources to see the truth for himself and he specifies that since the Shiites are accused of infidelity and exaggeration, he only uses the books by the Sunnites. After many efforts he realizes that the Shia sect conforms to the reason, Koran and reports given in the books of other sects and the contradictions of other sects do not exist in it and thereby he becomes a Shiite.

\section{The Books of Dala'el (Note 10)}

Part of Shiite historical books is those which are basically written for recording the miracles of the Imams with the purpose of substantiating Emamat and talking about their virtues. Naturally, some part of the historical lives of Imams is provided. Since the book Dala'el-un Nobovvah was written by the Sunnites to, on the one hand, describe the miracles and virtues of The Prophet and, on the other hand, to reject Shiite beliefs, Dala'el-ul Emamah was written to prove the rightfulness of Shia in believing that the Imams too had miracles as The Prophet had. The books of Reasons have three characteristics; first, they are the attempts made by the Shiites to defend their faith and prove the rightfulness of Shia leaders; second, they provide evidence from Nabavi Hadiths; and third, in addition to presenting miracles and virtues, they contain some parts of the history of Shiite Imams. Shiite works in this regard include:

1. Dala'el-ul Emamah; written by Abi Ja'far Muhammad Ibn-E Jarir Ibn-E Rostam Tabari (fifth century AH). The book starts with the life of Hazrat Zahra and goes on to the twelfth Imam. Using of Hadiths in the discussions of this book is obvious; however, the chapter related to Imam Zaman is unique because stating the facts in this manner has had no precedents in Hadith books. In this chapter, the author enumerates the companions of Imam Zaman at the time of his Reappearance and mentions their number and nationality (Tabari, 1413).

2. Nozhat-ul Keram Wa Bostan-ul Awam; its author is Jamal-uddin-al Mortaza Muhammad Ibn-E Hussein Ibn-E Hassan Razi (sixth and seventh centuries AH). The book is a short account of the values and virtues of Shiism and the miracles of The Innocent Ones. The book is in Persian and in two volumes (Tehrani, 1408, v. 3, p. 108). This book is one of the sources of Ibn-E Tavoos for his book Faraj-ul Mahmum (Coleberg, 1371).

3. Beshart-ul Mustafa Le Shiat-el Mustafa; by Abu Ja'far Muhammad Ibn-E Abel-Qasem Tabari, known as Imaduddin Tabari (living in AH 553) is on substantiating the rightfulness of Shia faith according to The Prophet's speeches. The style of the book is narrative and the author has collected and compiled the narrations with their full evidences (Tehrani, 1408). The book was in 17 parts and now 11 parts are left. It is considered one of the useful resources on proving Shia's rightfulness.

4. Al-Kharaej wa-l Jarahe'; it is written by Qotbuddin Ravandi (died AH 573), one of the great Shiite scholars in the sixth century after Hegira. This book is about the Prophetic miracles and Imams' virtues, which is organized by quoting narrations about each subject. Though it is organized according to narrations, Kharaej is a historical book because most of its narrations are reports and incidents of The Prophet's and the Imams' lives. In Kharaej, Ravandi does not mention any sources. He also does not refer to the sources of narrations when he is giving a report, except in certain cases when he provides the sequence of evidences. For example, he quotes a narration with evidences from Imam Kazem in the introduction to his book, when he is talking about the stature of the miracle of Sokhan (Note 11) (Ravandi, 1409).

\section{Manaqeb-Negari (Note 12)}

In some historical periods, "Manaqeb-khani” (Note 13) was customary among Shiites and its counterpart among Sunnites was called "Fazilat-khaani" (Note 14) in which they praised The Prophet's followers and this tradition was widely practiced in the fifth and sixth centuries (Qazvini, 1358). This subject sometimes led to violence. During the time of the Caliph Mostaz'i, one of the Shiites of Karkh district who recited "manqabats" in Baghdad bazaars was arrested and murdered by Baghdad policemen (Ibn-E Jozi, 1415). Reciting Manqabats can be likened to the panegyrics of today. In fact, Manqabat reciters praised the virtues and admirable qualities of the Imams and speak favorably about them. The Shiites, who always strived to defend their school and leaders, 
compiled Manaqeb books. Writers of Manaqeb books had different motivations for writing such books; defending the unquestionable rights of Ahl-E Bait, expressing courtesy and subordination to their holiness, confronting wrong notions of the opposers, responding to the existing doubts and feeling religious obligation for expressing the realities are some of the motivations of the authors of such books. Using Hadiths in writing Manaqeb is an important feature of this book, especially providing evidence from Nabavi Hadiths to prove the rightfulness and virtues of Imams. In terms of religion or religious tendencies, authors of the books on Ahl-E Bait's Manaqeb were not exclusively Imami Shiites, but many authors from both of the known Islamic faiths, i.e. Sunni and Shia, have written in this field. Among various sects of the Sunni faith, writers with Maleki, Hanbali, Mo'tazeli and especially, Shafe'i inclinations and in Shia, some authors with Zeydi inclinations can be noticed; for instance, Hakem Neishaburi, who had several works (Hadith-ul Teyr, Fazael-un Fatemah and Manaqeb-u Reza) on Ahl-E Bait's Manaqeb, had Shafe'i faith. Ibn-ul Maqazeli Maleki has written Manaqeb Ahl-E Bait and Eskafi Mo'tazeli has written Al-me'yar wa-l Movazenah fi Tafzil-E Ali Alayh-es-salam in this style. Muhammad Ibn-E Suleiman Kufi, author of Manaqeb Amir-al Mo'menin Ali Ibn-E Abi Talib, had Zeydi Shia faith. The most important Manaqeb books by Imami Shiites include:

1. Al-thaqeb Fil Mo'jezat-ul Baherat Len-Nabi wa-l Aemma-tal-Ma'sumin-al Heda; written by Abu Ja'far Emaduddin Muhammad Ibn-E Ali Ibn-E Hamzeh Toosi (died AH 585) known as Ibn-E Hamzeh Toosi was a great Shiite jurisprudent of the sixth century after Hegira. One of the sources of this book is Hakem Neishaburi's Mafakher-u Reza. The book, in 15 chapters, is dedicated to presenting the virtues of The Innocent Ones, categorized based on narrations in different topics. Apparently, Ibn-E Hamzeh has been one of the disciples of Sheikh Toosi (Musavi Khansari, 1408).

2. Ibn-E Shahrashub's (died AH 588) Manaqeb Al-e Abi Talib; though the title of the book suggests that the book only deals with the virtues of Al-e Abi Talib, it deals with the virtues of The Fourteen Innocent Ones and ends with describing the virtues of the eleventh Imam. The author of Al-Zari'a believes that Manaqeb had contained the life of the twelfth Imam because Ibn-E Shahrashub cites this book when he is describing the appellation of Sheikh Mofid in Ma'alem-ul Olama and now it does not exist in the book and it should be about the life of Hazrat Hojjat (Note 15) who called Sheikh Mofid with this appellation (Tehrani, 1408). The author states that his intention was to describe the Imams' and The Innocent Ones' virtues using Sunnite sources (Ibn-E Shahrashub, 1991). Indeed, the author refers to Shiite books, too and quotes narrations from them.

3. Ibn-E Betriq's Books; Sheikh Abul-Hassan, Yahaya Ibn-E Hassan Ibn-E Hassan Ibn-E Ali Muhammad Ibn-E Betriq-E Helli Asadi Reb'i (died AH 600) was born in the city of Hillah (Ibn-E Hajar Asqalani, 1406). His books of Manaqeb include: 1. Al-Mustadrak-il Mokhtar fi Manaqeb Vasy-al Mokhtar; this book consists of six hundred Hadiths from public books on the virtues of Amir-al Mo'menin (Tehrani, n.d.; Majlesi, 1983); 2. Al-umdah fi Oyun-el Sehah-el Akhbar fi Manaqab-e Imam-al Abrar; the book contains 913 Hadiths from public and special books. The feature of Al-umdah is that the author quotes Sunnite narrations not merely from the books, but through sequences of evidences offered by the authors of those books; in other words, he quotes them as a narrator not a writer. As a result, his book is important for the Sunnites, too and he mentions the fact himself (Ibn-E Betriq, 1412).

4. Al-fazael; it is the work of Shadhan Ibn-E Jebraeil Qomi (living in AH 593), one of the great Shiite scholars of the sixth century. This book is a fact-based defense of the special station of the Innocent Imams, particularly Amir-al Mo'menin Ali. The author has attempted to introduce Ali's virtues by means of Nabavi narrations to all Moslems, whether Shiite or Sunnite (Tehrani, 1408).

\section{Books of Maqatel (Note 16)}

This type of historiography thrived with the aim of recording incidents in wars with emphasis on the martyrdom of The Innocent Imams, Imam Hassan and Imam Hussein. Not all Maqatel writers were historiographers, but they embarked on writing such historiographies considering the necessity of recording the life of the Imams and injustices done to them. Using Hadith and narration in the materials in order to demonstrate the oppression the Ahl-E Bait suffered is one of the features of these books.

1. Masir-ul Ahzan; a work by Najmuddin Ja'far Ibn-E Muhammad Ibn-E Ja'far Ibn-E Abel-Baqa' Hebat-ullah Ibn-E Nama known as "Ibn-E Nama Helli" (died AH 645) written concerning the event of Ashura and it also deals with the life of Imam Hussein from birth to martyrdom.

2. Al-Malhuf Ala Qatlil Tafuf; written by Ali Ibn-E Musa Ibn-E Ja'far Ibn-E Tavoos (died AH 664); it is an abridged "Maqtal" to be suitable for the limited time of pilgrims (Sayyid Ibn-E Tavoos, 1414). One of the unique reports of Sayyid Ibn-E Tavoos is the famous Hadith of Mashyiat (Note 17) about the conversation between 
Imam Hussein and Muhammad Ibn-E Hanafyiah when Imam is leaving Mecca. In this Hadith, two famous statements by Imam Hussein as he quotes from The Prophet are mentioned: the first one is in response to the question "why is Imam leaving Mecca?" and he answers, "God wants to see you sacrificed" and the second which in response to the question "why is Imam taking the women with him?" he says, "God wants to see you captivated" (Ibid). This report has not been given in any other sources before Malhuf, but Ibn-E Taboos quotes this report from an old source called Asl by Ahmad Ibn-E Hussein Ibn-E Omar Ibn-E Barideh who quotes it from another person named Muhammad Ibn-E Davood Qomi (Ibid).

\section{History and Lives of the Innocents}

As the Shiites embarked upon writing Dala'el and Manaqeb books, writing historical and biographical books about The Innocent Ones was another part of the efforts by Shiite scholars. These books enjoy some common characteristics: first, they are history of The Innocent Ones' lives and their description; second, there is an ideological intention in writing these books; in fact, in addition to the history of The Innocent Ones' lives, these books deal with The Innocent Ones' high personality and stature and defend their rightfulness. Besides historical discussions, Qotbuddin Ravandi is concerned in his book with theological subjects and tries to defend Shiite tenets. The other point is the historical usage of these sources. Beside the history and lives of The Innocent Ones, relating the incidents associated with The Innocent Ones during those times can be used and referred to by historians and researchers. Describing the history and lives of The Innocent Ones requires reporting their statements which explains the importance of Hadith in such books.

1. Qotbuddin Ravandi's (died AH 573) Ghesas-ul Anbia; it the history and biography of divine prophets organized in twenty chapters. Ghesas-ul Anbia is compiled in historical-theological method and in which the history and biographies of prophets' lives are provided with reference to narrations and Hadiths. This book should be considered one of the most crucial and documented of works about previous prophets. In the section related to Dala'el Books, Qotb Ravandi's books Al-Kharaej and Al-Jaraeh were explained. Ravandi's two books, Ghesas and Kharaej are used because in them he combines history and theology and what he reports are virtues, miracles and magnanimity of prophets and the Imams. The second feature is his Hadith method; like other historiographers who have reported history using Hadiths, he also explains incidents and events in the form of Hadiths and narrations; we should consider the fact that Ravandi never comments on the narrations and reports he cites.

2. E'lam-ul Wara be A'lam-el Hoda; it is a book by Amin-ul Eslam Tabarsi (died AH 548), author of well-known Koran interpretation Majma-ul Bayan. E'lam-ul Wari together with Mofid's Al-Irshad, Erbeli's Kashf-ul Qame and Ibn-E Fattal Neishaburi's Rozat-ul Wa'ezin are valuable works written about the lives of The Fourteen Innocent Ones. These books are valuable because their authors tried to compile biographies of The Innocents using preceding sources and present them to Moslems, especially the Shiites. Since Tabarsi, like Abdul Jalil Qazvini (author of Al-naqz) was a moderate Shiite, he maintained that moderation in his book in order to prevent instigations against Shiites (Ja'farian, 1376).

3. Ramesh Afzay-e Al-e Muhammad; Muhammad Ibn-E Hussein Muhtaseb (died fifth century AH), master of Sheikh Montajebuddin, has compiled this book, about history of prophets and Imams, in ten volumes which unfortunately do not exist today, but Montajebuddin had seen the book and recited some part of it for the author (Montajebuddin, 1366, pp. 165-166). Also in Al-Zari'ah, references to some quotations in this book are given by Jamal-uddin Yusof Ibn-E Hatam Shafei and Razi-uddin Ibn-E Tavoos (Tehrani, 1408).

4. Rozat-ul Wa'ezin wa Basirat-ul Motta'ezin; a work by Muhammad Ibn-E Fattal Neishaburi (died AH 508). A historical-theological book, it deals with the history of The Twelve Imams' lives. The Hadith narration manner is evident in the book. The feature of the book is that it presents its materials without giving reference to the sources. Rozat-ul Wa'ezin is organized in the form of "scenes" (Note 18) including Ashura Insurrection which is presented in one scene (Ibn-E Fattal Neishaburi, 1381).

\section{Conclusion}

A close look at the works produced by Imami Shiites during the period between the fifth to seventh centuries after Hegira indicates that the Shiites have been perseverant and assiduous in most historiographical branches; a claim which is substantiated by the number of useful works produced by them. During the later period of Buyid supremacy to the fall of Baghdad, the Shiites, though a minority in terms of population and political power, produced great scholars some of whom are eminent in various scientific fields and attention to historiography is manifest in their works. The other point is the attitude and tendency of Shiite historiographers. Shiites' historiographical endeavors in different branches have been different in regard with the sociopolitical conditions of their times. As compiling books on general or local history was not customary among the Shiites because 
writing such books entailed praising and extolling the rulers and thereby sanctioning their actions, Shiites' efforts in some historiographical branches such as Taraajom and Rejaal, Ansab, Dala'el writing, historical-theological books and books on lives of The Innocents were very fruitful. In producing historical works Shiites pursued two important goals: first, describing Shiites' achievements and reporting and maintaining them for posterity a goal which was fulfilled to some extent by Taraajom and Rejaal books. Second, since Shiites were a minority group in the Islamic society and were always assaulted for their beliefs, a large part of their works was written in order to defend the tenets of their faith and refute accusations. Compiling such works required using Hadiths and narrations. That is why historical books of Shiites in this era are replete with Hadiths used for explaining their positions, proving their rightfulness and defending their beliefs because Hadiths and narrations are the best evidences in writing such works. It is especially the case for some authors who, in order to substantiate what they are saying, use Hadiths upon which there is public consensus so that they would have provided solid reasons for defending Shiite tenets.

\section{References}

Afandi Esfahani, M. A. (1369). Riaz-ul Olama wa Hiadh-ul Fozala. Qom: Khayyam Publications.

Ameli, S. M. A. (1403 AH). In S. H. Amin A'yan-u Shi'a. Beirut: Dar-ul Ta'arof.

Amin, M. (1403 AH). In S. H. Amin, A'yan-u Shi'e. Beirut: Dar-ul Ta'arof.

Christiansen, A. (1378). Iran at the Time of Sassanids. Tehran: Seday-e Mo'aser.

Dashti, M. (1384). Nahj-ul Balaqah. Qom: Amir-al Mo'menin Cultural and Research Institute.

Haji Khalifeh, M. A. (1412 AH). Kashfu-Zonun. Beirut: Dar-ul Azwa.

Hemavi, Y. (1408 AH). Mo'jam-ul Odaba. Beirut: Dar Ehya-al Torath-ul Arabi.

Ibn-E Enabeh, A. I. A. (n.d.). Omda-tu Taleb fi Ansab Al-e Abi Taleb. Beirut: Dar-u Maktabat-ul Hayat.

Ibn-E Betriq, Sh. A. (1412 AH). In M. Mahmudi, \& E. Naderi, Al-umdah fi Oyun-el Sehah-el Akhbari fi Manaqeb-el Imam-el Abrar. Tehran: Representative of Leader Sayyid Khamenei.

Ibn-E Fattal Neishaburi, M. (1381).In Q. Majidi, \& M. Faraji, Rozat-ul Wa'ezin wa Basirat-ul Motta'ezin. Qom: Dalil-e Maa.

Ibn-E Hajar Asqalani, A. I. A. I. H. (1406). Lesan-ul Mizan. Beirut: A’lami Institution Publications.

Ibn-E Jozi, A. F. (1415). Collection of Kings and Nations Histories. Beirut: Dar-ul Fekr.

Ibn-E Shahrashub, M. I. A. (1380 AH). Ma'alem-ul Olama. Najaf: Heydaryieh Press.

Ibn-E Shahrashub, (1991 AD). Virtues of the House of Abi Talib. Beirut: Dar-ul Azwa.

Ibn-E Tavoos, R. (1414 AH). In F. Tabrizian, Al-malhuf ala qat-lil Tafuf. Dar-ul Oswah.

Ja'farian, R. (1376). Sources of Islamic History. Qom: Ansarian.

Ja'farian, R. (1379). Historical Essays. Qom: Al-Hadi Press.

Khansari, M. B. M. (1391 AH). Rozat-ul Jannaat. Qom: Esmaeilian Publications.

Kohlberg, E. (1371). The Collection of Ibn-E Tavoos and His Life. Qom: Library of Ayatollah Mar'ashi Najafi.

Majlesi, M. B. (1983 AD). Behar-ul Anwaar. Beirut: Dar Ehya-al Torath-al Arabi.

Mar'ashi Najafi, S. Sh. (1410 AH). Kashf-ul Ertyiab fi Tarjomate Sahebo Lobab-el Ansab. Qom: Library of Ayatollah Mar'ashi Najafi.

Marvzi Azvareqani, A. E. I. H. (1409 AH). In S. M. Rejayi, Al-fakhri fi Ansab-al Talebyin. Qom: Library of Ayatollah Mar'ashi.

Montajebuddin, A. I. O. I. B. (1366 AH). In S. J. Mohaddeth, Fehrest Asma' Olama-ul Shi'a wa Mosannfeihom. Qom: Library of Ayatollah Mar'ashi Najafi.

Manzari, Z. A. I. A. (1401 AH). In B. A. Ma'ruf, Al-takammola le-l vafyiate-l naqlah. Beiry: Al-Resalah Inst.

Musavi Khui, S. A. (1403 AH). Mo'jam Rejaal-ul Hadith. Qom: Madina-tul Elm.

Najjashi, A. I. A. (1408 AH). In M. J. Naini, Al-Najjashi's Rejaal. Beirut: Dar-ul Azwa.

Qazvini Razi, A. J. (1358). In M. J. Mohaddeth, Ketab-ul Naqz. Tehran: National Works Association.

Rafe'I Qazvini, A. I. M. (1408 AH). In S. A. Atarodi, A-tadvin fi Akhbar-e Qazvin. Beirut: Dar-ul Kotob-al Elmyiah. 
Ravandi, Q. S. (1409 AH). Al-Kharaej wa-l Jarahe’. Qom: Al-Imam al Mahdi Inst.

Safdi, S. Kh. I. A. (1405 AH). Alwafi Bel-vafyiyat. Beirut: Daar Sader.

Shushtari, M. T. (1422 AH). Qamus-u Rejaal. Qom: Islamic Publications Institute.

Tabari, A. J. M. (1413 AH). Dala'el-ul Emamah. Qom: Be'sat Foundation.

Tehrani, A. (1337). Selected Speeches by Rejaal Authors. Tehran: Iranian State Press.

Tehrani, A. (1408 AH). Al-zari'a ila Tasanif-el Shi'e. Qom: Esmailian.

Tha'alebi, A. M. A. (1353). Tatemmat-al Yatimah. Tehran: Fardin.

Toosi, A. J. M. I. H. (1424 AH). In S. A. Musavian, \& M. T. Fazel Meybodi, Ekhtyiar Ma'refat-u Rejaal. Tehran: Ministry of Islamic Culture and Guidance.

Zarkali, Kh. (1989 AD). Al-A 'laam. Beirut: Dar-ul Elm Lel Malayin.

Zehbi, Sh. M. I. A. I. O. (1409 AH). In O. A. Tadmori, History of Islam and Deaths of Dignitaries Luminaries (2nd). Beirut: Dar-ul Kotab-ul Arabyiah.

\section{Notes}

Note 1. Figures.

Note 2. Biographies.

Note 3. Reason.

Note 4. Shiites following the principles of the 12 Shia Imams.

Note 5. As'haab.

Note 6. Prophetic.

Note 7. Mohajaat.

Note 8. Nowab-e Arba'e.

Note 9. Nahyieh Moqaddaseh.

Note 10. Reasons.

Note 11 . Word.

Note 12. Recording the Virtues.

Note 13. Reading Out the Virtues.

Note 14. Reading Out the Virtues.

Note 15 . The 12th Shiite Imam.

Note 16. Murder Sites.

Note 17. Divine Will.

Note 18. Majles. 